\title{
Solidarity, stance, and class identities
}

\author{
J U L I A S N E L L \\ University of Leeds, $U K$
}

\section{A B S T R A C T}

Scholars have explained working-class speakers' continued use of stigmatised vernaculars as a response to their relative powerlessness in relation to the standard language market. Research has shown how, in the face of this powerlessness, working-class communities turn to group solidarity, and use of the vernacular is seen as part of this more general orientation. As a result, two competing social values - status and solidarity-have featured prominently in discussions around language and class. I expand these discussions using data from a linguistic ethnographic study of children's language in Teesside, England. I argue that meanings related to status and solidarity operate at multiple levels and cannot be taken for granted, and demonstrate that vernacular forms that LACK status within the dominant sociolinguistic economy may be used to ASSERT status within local interactional use. I further advance discussion of the ways local vernaculars might be intimately linked to classed subjectivities. (Social class, variation, solidarity, status, stance, indexicality, identity, interaction, ethnography)*

\section{N T R O D U C T I O N}

Speakers in the UK face continuing pressure to moderate, or even erase, their local accents and dialects and conform instead to prestige 'standards' (see e.g. Garner 2013; Williams 2013; Drummond 2016). Despite this pressure, local 'vernaculars'1 remain strong in many communities, especially those characterised as traditional working-class communities. Sociolinguistic research has explained workingclass speakers' adherence to local vernaculars as a response to their relative powerlessness in relation to the demands of the 'standard language market' (Bourdieu \& Boltanski 1975). Scholars have emphasised how, in the face of such powerlessness, working-class and other marginalised communities turn to local support and group solidarity, and use of the vernacular is seen as part of this more general orientation (L. Milroy 1980; Woolard 1985; Rickford 1986; Eckert 2000:18). As a result, two competing social values - status and solidarity - have featured prominently in discussions around language and social class (e.g. Woolard 1985; Milroy \& Milroy 1997; Doran 2004). In this article, I attempt to expand these discussions using data from a linguistic ethnographic study of children's language in Teesside, north-east England. My starting point is that a robust link between working-class 
speech and solidarity-based ideologies has developed in sociolinguistic research, but this link did not explain, in any straightforward way, the findings that emerged from the Teesside study. The working-class children who participated in this study certainly made energetic use of the local vernacular, but not always in ways that foregrounded solidarity and in-group identity; in fact, salient features of the local vernacular were often used to negotiate hierarchy and status differentials in the peer-group, and to exclude, rather than convey a sense that 'we're all in it together'. My aim in this article, then, is to understand the different ways in which meanings related to status and solidarity may (or may not) be implicated in the interaction between language and class identities, and to apply these understandings to the issue of vernacular maintenance. In doing so, I aim also to open up discussion of the ways that local vernaculars might be intimately linked to classed subjectivities.

I begin by tracking the emergence of status and solidarity as key concepts within early work on language variation and language attitudes. I then compare the approach to language and social class taken in this body of work with more recent research conducted by scholars working within what has come to be known as the 'third wave' of variation study. Third wave research has drawn, in particular, on concepts from linguistic anthropology, such as stance and indexicality, which I outline as important components of my own theoretical orientation. Next, I introduce the Teesside study before presenting some of the data and analyses that emerged from it, focusing on two salient features of the local dialect: right dislocation (e.g. That's just stupid, that; She's a liar, her); and howay, a discourse-pragmatic feature unique to north-east England. Finally, I interpret my findings in relation to the aims outlined above, arguing that ideologies of working-class solidarity may be part of the wider meaning potential or indexical valence of Teesside dialect forms, but it is the more immediate indexicalities of stance and act that are most relevant for speakers/hearers when they use/interpret these forms in interaction, and here, dialect forms that LACK status within the dominant sociolinguistic economy may be used to ASSERT status within the local community. More broadly, I suggest that differences in the frequency of use of vernacular forms between class-differentiated groups might best be explained by consideration of the different social goals, acts, and stances in which they are engaged; and that these social goals, acts, and stances may constitute a form of class-based practice that endures across social and geographical boundaries.

SOCIAL CLASS IN VARIATIONIST RESEARCH: STATUS VERSUS SOLIDARITY

There has been a remarkable consistency in the patterns that have emerged from survey studies of language variation and social class, beginning with Labov's (1966) seminal New York City (NYC) study, and continuing with those that followed in its wake (for a general overview see Dodsworth 2010). Most relevant to 
this article is the finding that despite quantitative differences between class groups, ALL speakers follow the same general pattern with regards to stylistic variation: speakers systematically increase their use of 'standard' forms (and decrease their use of vernacular forms) as their perception of the formality of the situation increases. This intraspeaker stylistic variation was theorised as being linked to intergroup variation, such that each group of speakers modelled their formal style on the speech behaviour of those who ranked slightly higher in the social scale (e.g. Bell 1984:151). In other words, class stratification in society was being replicated within speakers' own stylistic behaviour, lending testimony to Bourdieu's (1977, 1991) point that speakers' mundane actions bear the traces of wider social structure.

The consistent patterns of style-shifting identified by Labov led him to make a general statement about the social stratification of NYC: 'New York City is a speech community, united by a common evaluation of the same variables which serve to differentiate the speakers' (Labov 1972a:106). This focus on shared sociolinguistic norms implied a consensus model of language and social class: everyone agrees which groups of speakers and associated linguistic features have the most status in society, and while speakers located at different positions in the socioeconomic hierarchy use language differently, they do so in relation to a shared set of norms dominated by an agreed 'standard'. This raised a key question: 'Why don't all people speak in the way that they obviously believe they should?' (Labov 1972a:249). In other words, why do vernacular forms persist given the pressure exerted by the standard? Labov's response was to posit an 'opposing set of covert norms, which attribute positive values to the vernacular' (249). This idea was taken up by Trudgill (1972) who argued that these values are related in particular to notions of masculinity, toughness, and group solidarity, and as such, affect male speakers more than female: 'Privately and subconsciously, a large number of male speakers are more concerned with acquiring prestige of the covert sort and with signalling group solidarity than with obtaining social status, as this is more usually defined' (1972:188). In other words, while the 'standard' is the sole source of Conscious sociolinguistic norms within a speech community, there exists a set of opposing but subConscious values, related to group solidarity, which circulate in the private sphere.

In her study of working-class communities in Belfast, L. Milroy (1980) also emphasised the link between use of the local vernacular and local solidarity, but contrary to the notion of covert prestige, she found quite OVERT pressure to adhere to the vernacular within the communities she studied (1980:60-61). These communities were characterised by relatively dense, close-knit networks, which Milroy argued functioned as mechanisms of 'vernacular maintenance' because they enabled speakers to resist pressure from outside. Speakers who made greatest use of vernacular forms were thus those most closely integrated into local networks. These speakers used the vernacular, Milroy argued, to signal local solidarity and loyalty to noninstitutional norms. Cheshire's (1982) study of adolescent peer groups in Reading arrived at similar conclusions. Her participants' use of 'nonstandard' 
morphological and syntactic features correlated with the extent to which they adhered to the norms of an oppositional vernacular culture (measured via a 'vernacular culture index') (see also Labov 1972b).

Woolard (1985) drew explicit attention to the 'special attachment' sociolinguists have had to the competing dimensions of status and solidarity, which she writes 'amount not simply to a theory of the social use of language, but to a guiding theory of social relations, certainly not original to, but nonetheless most extensively elaborated by sociolinguists' (1985:739). Drawing upon the way these concepts had been illuminated in sociolinguistic work (including her own work in Catalonia), Woolard (1985) argued that speakers do not simply use the vernacular in situations in which pressures from the standard language market are relaxed (i.e. in the 'private sphere'); rather, speakers in working-class and minority communities face significant social pressure to orient to alternative or opposing solidary norms. This formulation implied a move away from consensus to a conflict model of language and class.

Rickford's (1986) work on sociolinguistic stratification in the village of Cane Walk is an early illustration of the explanatory value of a conflict-based model. Rickford found dramatic differences in the speech of the two groups he studied. The speech of the 'Estate Class' (EC), composed entirely of fieldworkers on the sugar estate, was overwhelmingly Creole, while the 'Non-Estate Class' were much closer to 'standard' English. Rickford argued that even though the EC members were aware of the status associated with 'standard' English, they actively chose to use Creole 'as a revolutionary act, as a means of emphasizing social solidarity over individual self-advancement and communicating political militancy rather than accommodation' (Rickford 1986:218). Likewise, the jock-burnout opposition in Eckert's $(1989,2000)$ ethnography of a Detroit high school foregrounded competing linguistic markets and conflict models of class, with jocks orienting to the standard linguistic market and the burnouts to the local, urban, vernacular market. More recently, Doran (2004) has shown how conflict between the norms and culture of the dominant elite in Paris and those of immigrant minority youth living in la banlieue has maintained and vivified Verlan, a 'street language' characterized by 'various alterations of Standard French terms, borrowings from such languages as Arabic, English, and Romani, and certain distinctive prosodic and discourse-level features' (Doran 2004:94). The youths who participated in this research expressed a strong 'sense of difference' (114) from dominant French society. This resided not simply in ethnic difference but also in their opposition to the class status and value system of les bourgeois (114). Set against this background, the use of Verlan was seen as an 'act of identity' (LePage \& TabouretKeller 1985), signalling alignment with the local multiethnic peer group and with the group's values, which were considered 'less individualistic, more communitarian, more friendly, and less snobbish than that of the typical bourgeois' (Doran 2004:114). While ready and able to use the 'official language' in formal settings, such as job interviews, the youths actively rejected it in the peer-group, orienting 
instead to Verlan 'as a means of asserting group identity and solidarity, and simultaneously resisting the authority (and hegemonic ideology) of the dominant language' (Doran 2004:115).

In this body of ethnographic work, adherence to alternative solidary norms is seen as an act of opposition to the demands of the standard market. As Eckert (2000:18) points out, this is 'not necessarily a reason to reject the supremacy of the standard market as constructed by Bourdieu and Boltanski (1975), for the creativity and the force of the vernacular can be seen as a response to relative powerlessness in the face of the standard'. Even where there is recognition of the status of the 'standard', then, there can simultaneously be a rejection of this 'standard' based on the contrasting dimension of solidarity (Woolard 1985:744). Milroy \& Milroy (1997:53) have emphasized that conflict between status- and solidarity-based ideologies in a community plays a key role in vernacular maintenance: ' $[w]$ hen the latter are dominant, localized noninstitutional norms of language will tend to be preserved'.

The existence of pressure towards a solidarity community norm has been further demonstrated in work on language attitudes, where two broad generalisations have emerged: (i) standard varieties tend to be rated highly in terms of status but lower in terms of solidarity, and (ii) vernacular varieties tend to be rated highly in terms of solidarity but lower in terms of status (e.g. Giles 1970; Giles \& Powesland 1975; Stewart, Ryan, \& Giles 1985; Bishop, Coupland, \& Garrett 2005; Hiraga 2005; Watson \& Clark 2015). In addition, where vernacular varieties are overtly stigmatised across вотн dimensions, there is some evidence to suggest that they may attract covert approval from speakers at a subconscious level (e.g. Kristiansen 2011).

THE THIRD WAVE: FROM COMMUNITY NORMS TO IN D I V I U A L S T Y L IS T I P R A T I E

Recent research on language variation has focused less on community-wide patterns and norms and more on individual stylistic practice. To the extent that social class has featured in this body of work, the focus has typically been on how class intersects with other social categories, especially ethnicity (e.g. Rampton 2010, 2011; Jaspers 2011; Kirkham 2015; Sharma \& Rampton 2015; Jaffe 2016; Madsen 2016), but also gender (e.g. Holmes-Elliott \& Levon 2017; Kiesling 2018) and place (e.g. Johnstone, Andrus, \& Danielson 2006; Johnstone 2013; Snell 2017). This research can be broadly situated within what has become known as the 'third wave' of variation study (Eckert 2012). Research within the third wave focuses on the situated creation of social meaning and the role that language plays in constructing (rather than merely reflecting) individual and group styles and identities. A central tenet of this approach is that ' $[\mathrm{v}]$ ariation constitutes a social semiotic system capable of expressing the full range of a community's social concerns', and given that these concerns are multiple, varied, and subject to change, 'variables [linguistic and otherwise] cannot be consensual markers of 
fixed meanings; on the contrary, their central property must be indexical mutability' (Eckert 2012:94).

Set against this theoretical backdrop, it becomes increasingly difficult to interpret whole varieties such as 'standard English' or 'Teesside English' as having fixed class-based meanings related either to status or solidarity; in fact, when we drill down to the way 'meaning-making unfolds in interaction' (Eckert 2012:95), it becomes clear that variation between 'standard' and 'vernacular' speech does not necessarily have direct class significance because the social meanings of variation are multivalenced. Coupland has demonstrated this convincingly in the reanalysis of his Cardiff travel agency study. In the original analysis (see e.g. 1980, 1984), he focused on the phonological style shifting of one travel agent, Sue, and interpreted the findings in Labovian class-based terms. However, he later demonstrates how the same phonological variables can index different meanings depending on the contextual frames in play (Coupland 2007). He reiterates the importance of social class within the 'socio-cultural frame' that is activated when Sue is speaking to a tour operator on the telephone, plausibly using more 'standard' phonological variants in order to project 'a more middle-class persona of the sort that still tends to gain status in public and especially work-place discourse' (2007:118). However, social class becomes irrelevant just a few seconds later when Sue enters into a discussion about dieting with her co-workers. Within this 'interpersonal frame' it is Sue's personal powerlessness in the face of a depressing diet that becomes relevant, and her marked vernacular style at this moment is interpreted as indexing meanings related to low personal control and incompetence (see also Coupland's (2001) analysis of Cardiff local-radio presenter, Frank Hennessy).

Coupland's work on the discursive framing of acts of identity highlights the different levels at which identity work takes place: macro-level (socio-cultural framing); meso-level (genre framing); and micro-level (interpersonal framing). This perspective aligns with others, such as Bucholtz \& Hall (2005:591-92), in demonstrating that 'language users often orient to local identity categories rather than to the analyst's sociological categories', and that these local identity categories are themselves the product of 'transitory interactional positions'. A focus for analysis in this line of work is how linguistic forms come to construct these interactional positions, and how these, in turn, come to calcify into more enduring identity categories. In other words, how might we understand the links between the different levels of identity? Linguistic anthropological approaches to stance and indexicality are fundamental in addressing this question.

The concept of stance refers to the processes through which speakers use language (along with other semiotic resources) to position themselves and others, draw social boundaries, and lay claim to particular statuses, knowledge, and authority in ongoing interaction (Du Bois 2007:163; Jaffe 2009). Interactional stances are fleeting, but these transitory social meanings may help to constitute more enduring social identities, roles, and relationships. This process has been outlined most extensively by Ochs $(1992,1996)$ in her influential account of how language 
indexes gendered identities, and has been taken up by a number of scholars working within the third wave (e.g. Podesva, Roberts, \& Campbell-Kibler 2001; Bucholtz 2009; Kiesling 2009).

Ochs (1996) describes how language has the capacity to index a range of sociocultural information, such as affective and epistemic stances, social acts (e.g. commands), and social identities (including roles, relationships and group identities). These different 'situational dimensions' are related to one another, Ochs argues, through a network of cultural associations, norms, and expectations, which are shared by members of a community. She refers to these as "culturally constructed valences' (1996:417). It is via these links or valences that, in theory, indexing one situational dimension (e.g. an epistemic stance) can help to constitute the meaning of any other situational dimension (e.g. a social identity). For example, tag questions in English have been associated with a feminine linguistic style, but the link between tag questions and the social category of gender is not direct. It would be more accurate to suggest that tag questions directly index a stance of hesitancy (e.g. The meeting is tomorrow, isn't it?) and only indirectly index female identity through a series of ideological conventions that associate hesitancy with femininity: '[i]t is in this sense that the relation between language and gender is mediated and constituted through a web of socially organized pragmatic meanings' (Ochs 1992:341-42). Ochs illustrates her argument in relation to gender, but the model can be applied to social identity categories more generally, including to class identities.

In its focus on speakers' cultural construals of linguistic form, stance, and self, Ochs' model foregrounds the important role of ideology in the study of language variation. As such, it represents one angle on a widespread orientation within linguistic anthropology to what Silverstein (1985:220) has termed the 'total linguistic fact'; that is, a commitment to studying the 'unstable mutual interaction of meaningful sign forms, contextualised to situations of interested human use and mediated by the fact of cultural ideology' (see also Eckert (2008) on the indexical field). It is this theoretical approach to language variation-one that combines linguistic form, situated use, and ideology - that I want to draw upon in my analysis of the Teesside data, using it to better understand the nature of the link between solidarity and class identities. First, a few words about the context of this study.

\section{B ACKGROUND TO THE ST U DY}

The analysis that follows is based on data collected during fifteen months of ethnographic fieldwork at two schools within the urban conurbation of Teesside, north-east England. 'Murrayfield Primary' and 'Ironstone Primary' are both Roman Catholic primary schools of similar size, but they are differentiated in terms of the socioeconomic profile of the areas they serve, and by implication, the social background of the pupils. Government census data and indices of deprivation (Office for National Statistics 2005) highlighted clear differences between 
the two areas across a number of criteria, including levels of education, employment, and housing. In relation to housing, for example, most people in the catchment area for Ironstone Primary were living in rented accommodation, primarily owned by the local authority. In contrast, many more people owned their own homes in the catchment area surrounding Murrayfield Primary, and these houses were worth on average almost three times more than those surrounding Ironstone Primary (reflecting the different levels of prestige associated with these areas). The distinction between the two areas is particularly marked when we consider the UK government's measures of deprivation. The index of multiple deprivation includes information on seven domains of deprivation: income, employment, health deprivation and disability, education skills and training, barriers to housing and services, crime, and the living environment. All 32,482 'output areas' in England are ranked according to how deprived they are relative to each other across these measures. Murrayfield Primary's output area was ranked somewhere in the middle, at 15,626 (where 1 is the most deprived and 32,482 the least deprived). In stark contrast, Ironstone Primary's output area was ranked 1,475 , much closer to the most deprived end of the scale.

These differences were reflected in the schools' Ofsted (Office for Standards in Education, Children's Services and Skills) inspection reports (published two years prior to the start of fieldwork). The report for Murrayfield Primary highlighted the stable nature of the local community and stated that the level of attainment of pupils when they enter the school 'meets expectations'. The report for Ironstone Primary, by contrast, drew attention to the 'social and economic challenges' endemic in the surrounding area and found pupil attainment on entry to be 'well below expectations'. It also reported that the percentage of children entitled to free school meals at Ironstone Primary was over three times the national average, a figure indicative of the 'economic challenges' faced by local residents (while at Murrayfield Primary entitlement was below the national average). In summary, Murrayfield and Ironstone Primary do not constitute the opposite extremes of the socioeconomic continuum, but there is clearly a great deal of social distance between them. In the rest of this article, I refer broadly to the children at Ironstone Primary as 'working class' and the children at Murrayfield Primary as 'middle class' in order to recognise clear differences in the social and economic realities of the two groups of children and to approximate the socioeconomic hierarchy that has been adopted in studies of language variation. ${ }^{2}$

Ethnographic fieldwork helped me to understand how these social and demographic differences translated into actual experience. I made weekly visits to the Year 4 class (age eight to nine years) in both schools and then followed the same groups of children into Year 5 (age nine to ten years). I participated in classroom life initially as an informal classroom helper, but later, I spent a significant amount of time with the children in the playground, chatting and playing games. Occasionally, I went to the staff room during breaks to talk to the teachers and listen to their conversations. Overall, I spent a considerable amount of time 
'lurking and soaking' as an ethnographer in both schools (Werner \& Schoepfle 1989). These observations augmented my understanding of the schools and their relationship to the local area. I learned, for example, that both schools were proud of their association with the local church and, through it, the local community. Within Ironstone Primary, in particular, there was a strong sense that the school was an integral part of the local community. The annual school musical, for example, was a community affair, held on two consecutive nights at the local community centre, accompanied by food and a more general social gathering (which I was able to experience in June 2007 when I attended their production of My fair lady). The local community later played a central role in helping the school to recover from an arson attack that occurred shortly after the end of my fieldwork. There was an overwhelming response from members of the local area who worked together with the Ironstone Primary teachers to ensure that lessons could continue (almost without interruption) in the church hall. Individuals approached local businesses, for instance, in order to secure vital classroom materials.

Children at Ironstone Primary included me in their gossiping about events that occurred with the local area. There were often significant (and sometimes very troubling) events to discuss, including two murders that took place during the period of the fieldwork. There were also many positive events and activities to talk about too, such as local discos, parties, and firework displays. Overall, it became clear that Ironstone Primary was situated in an area characterized by the kinds of close-knit networks and sense of communal pride that has been documented as characteristic of traditional working-class communities. I am not able to give a similar account of the relationship between Murrayfield Primary and its surrounding community because the children rarely spoke to me about people, places and activities related to the local community, and there were certainly no events as significant as murder or arson to discuss. These children did occasionally tell me about some of the out-of-school activities they participated in, such as dance classes, but these were generally held outside of the immediate area and were attended by children from a number of different schools and areas.

After seven months of making weekly visits to the schools and engaging in participant observation, I began recording the children using a radio-microphone. The radio-microphone enabled the children to move around freely while being recorded, participating in their normal daily activities. I collected over seventy-five hours of data, and analysed a subset of this - twenty-five hours per schoolinvestigating in detail four salient features of the local dialect. I focus here on two of these features: right dislocation and howay (but see also Snell (2010) on possessive $m e$ and Snell $(2013,2015)$ on singular $u s)$. In the analysis that follows I demonstrate that the children's use of these features appears to runs counter to the prevailing notion that vernacular forms are stigmatized as having low status by wider society but associated more positively with group solidarity at a local level. 
Right dislocation refers to the phenomenon whereby a clause is followed by a tag that is coreferential with the preceding subject or object pronoun. The tag may be a full noun phrase (as in They do have guns, police; Is it brown or blond, your hair) or a pronoun (That's just stupid, that; He's mad, him). Right dislocation with noun phrase tags is well documented in English grammars, where it is noted to be a feature of informal spoken (and some written) discourse (e.g. Quirk, Greenbaum, Leech, \& Svartvik 1985; Biber, Johansson, Leech, Conrad, \& Finegan 1999; Huddleston \& Pullum 2002). These grammars typically assign an emphatic, clarifying, or focusing function to noun phrase tags and acknowledge that they are well suited to the needs of conversation. Demonstrative tags (e.g. That looked good, that) are likewise acknowledged by standard grammars, being accepted as part of 'informal spoken standard English' (Biber et al. 1999:958). Personal pronoun tags, by contrast, are largely absent from standard grammars. They have been documented instead in dialect grammars (e.g. Wright 1905; Shorrocks 1999) and in some grammars of the spoken language (e.g. Carter \& McCarthy 1995:150). This distinction suggests that pronoun tags are not generally considered to be a feature of 'standard' English. There is also regional variation in pronoun tags. For example, in Yorkshire the pronoun is often preceded by an auxiliary verb, as in He's got his head screwed on, has Dave (Beal 2004:135-36; see also Durham 2007), but this form has not been documented in Teesside.

In addition to the discourse management functions highlighted by grammars (i.e. emphasis, clarification, focus), corpus and discourse analysts have identified a range of interpersonal meanings associated with right dislocated tags, including pronoun tags. In particular, these scholars have demonstrated that right dislocated tags regularly express affective and attitudinal meanings, often carrying 'considerable evaluative force' (Timmis 2010:11; see also Aijmer 1989; Carter \& McCarthy 1997; Carter, Hughes, \& McCarthy 2000. Carter \& McCarthy (1995:151) thus argue that right dislocated tags (which they refer to as 'tails') are 'an important part of what may be called interpersonal grammar, that is to say speaker choices which signal the relationships between participants and position the speaker in terms of his/her stance or attitude'.

Studies that have investigated social variation in the use of right dislocation have found a greater propensity for working-class speakers to use right dislocated tags, for example in Bolton (Moore 2003), Hull (Cheshire 2005), and Ayr and Glasgow (Macaulay 2005). In the Teesside data, noun phrase and demonstrative tags were used consistently across both schools (see Figure 1). However, there is a marked difference in the use of personal pronoun tags, with the children at Ironstone Primary using these tags more frequently than those at Murrayfield Primary (Figure 1). In addition, personal pronoun tags occurred only in informal peercentred spaces and tasks, never during formal centre-stage classroom talk; and 


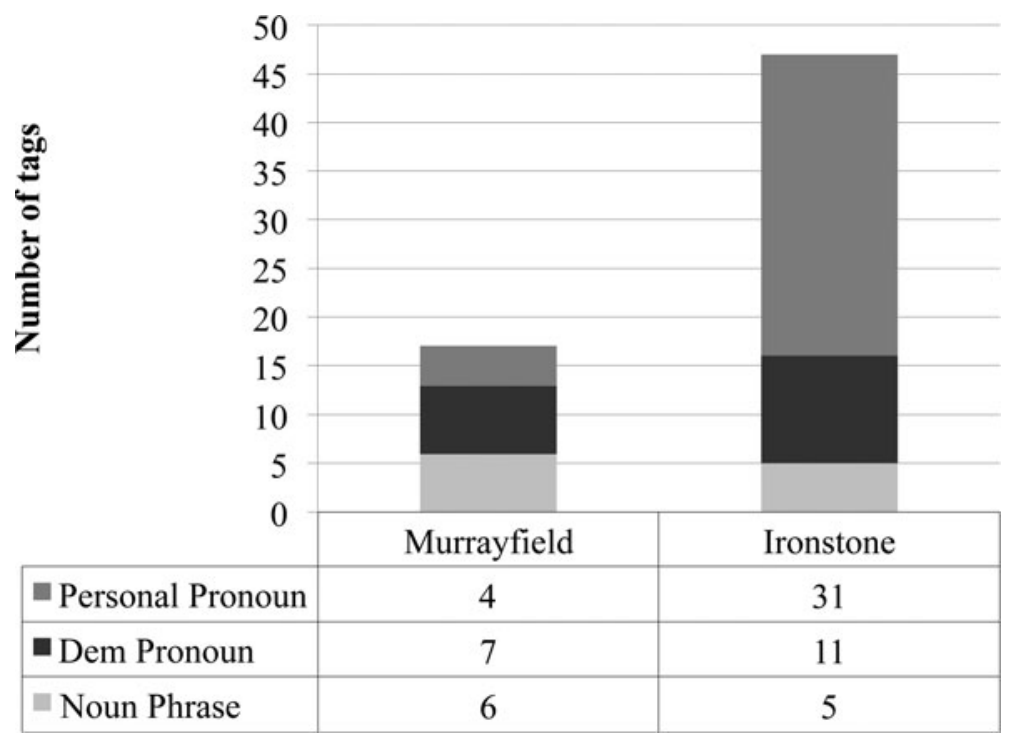

FIGURE 1. Right dislocation across both schools.

while noun phrase tags did crop up in talk with adults (e.g. three of the six noun phrase tags at Murrayfield were directed to adults) pronoun tags occurred almost exclusively with other children. The distribution of personal pronoun tags in the Teesside data therefore aligns with the familiar quantitative class-based patterns that have been highlighted by variationist research. However, the differences between the two groups of children extend beyond straightforward differences in frequency of use.

Figure 2 shows the distribution of personal pronoun tags between the two schools by TYPE of pronoun. It shows that both groups of children make some use of first person singular pronouns (e.g. I want that one, me); but all other personal pronoun contexts (with the exception of just one third-person singular tag) are absent from the Murrayfield Primary data. It seems, then, that these two groups of children may differ from one another with regards to communicative preferences of a more qualitative kind. To explore this further, it is necessary to examine the use of pronoun tags in context.

Extract (1) occurred when Ironstone Primary pupil Clare was wearing the radiomicrophone during the lunch break. She is eating lunch in the dining hall with Danielle, Tina, Joanne, and Rosie. These five girls all regularly brought their own lunch to school and often traded items of food. Occasionally, as in (1), this practice caused arguments. Here the focal point of the argument is Clare's chocolate bar, and who has (or has not) been given a piece. 
JULIA SNELL

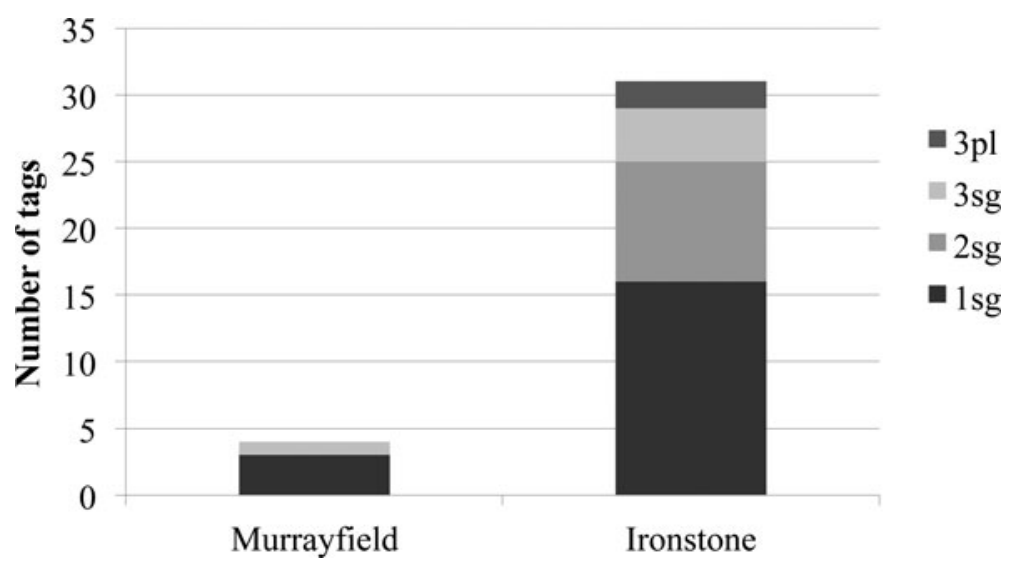

FIGURE 2. Distribution of right dislocated personal pronouns across schools.

(1) She's a liar, her ${ }^{3}$

1 Danielle: ere I'll give you one of these for one

2 Clare: I've just give you o:ne

3 (1)

4 Danielle: I mean it

$5 \quad$ I haven't got one

$6 \quad$ Tina took it off me

7 Tina: no I haven't ((talking with mouth full))

8 look there's my own

9 you know I don't-

10 Clare: what're you eating now then

11 (.)

12 howay

13 Danielle: crisps ((laughs))

14 Clare: no:

15 crisps and chocolate

16 see

17 so give me my $(\mathrm{xxxx})$

((45 seconds later $))$

18 Tina: what's she eating

19 Anon: I don't know

20 Danielle: you're not getting any of mine then (hhh) ((laugh))

21 Clare: good

$22 \quad(1)$

23 I've got my own thanks

24 Danielle: no you haven't 
25 Clare: not [any more cos you nicked ${ }^{4}$ half of it ((shouting with mouth full))

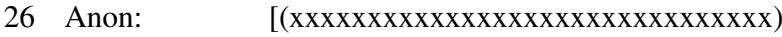

27 Tina: oh shut up

28 Danielle: I nicked two not half

29 Clare: ((laughing))

30 Danielle: she's a liar her

$31 \quad$ I hate her

32 Clare: nicked two pieces though

33 Tina: yeah but you're a liar

$34 \quad(1)$

35 you're a liar

There is no doubt that the utterance containing the third person right dislocated pronoun tag on line 30 is intended to negatively evaluate Clare, and quite aggressively so. The tag emphasises both the strength and the target of the evaluation, as does the immediate repetition of her in "I hate her" (line 31). In line with discourse and corpus-based studies of right dislocation (cited earlier), personal pronoun tags in the Teesside data were frequently used in these kinds of overt evaluative practices, typically co-occurring with items of evaluative lexis, such as emotion verbs (e.g. like, hate, love) and evaluative adjectives (e.g. shit, old, mad, nasty). These evaluations were often negative, as in extract (1), and in the following examples.

- He's shit, him.

(Aaron, Ironstone Primary)

- I hate this book bag, me.

(Robert, Ironstone Primary)

- He's mad, him.

(Robert, Ironstone Primary)

- You are a copy-cat, you.

(Sam, Ironstone Primary)

- You're dead nasty, you now. (Aaron, Ironstone Primary)

- She's horrible, her.

(Michelle, Murrayfield Primary)

However, there is more at stake than just the expression of evaluation and affective meanings. Scholarly work on stance taking has highlighted that when speakers take an evaluative stance, they are simultaneously taking a stance of alignment or disalignment with respect to others in their social space (Goodwin 1990, 2006; Bucholtz \& Hall 2005; Du Bois 2007). In extract (1), the right dislocated pronoun draws explicit attention to this act of positioning. Danielle openly disaligns with Clare and positions her as outside of the immediate social grouping through the use of the third person pronoun, which suggests that Clare is no longer a ratified participant in this exchange. On line 33, Tina aligns with Danielle's stance (as she acts as 'animator' of Danielle's words). Further, in negatively evaluating Clare as a liar, Danielle also implicitly evaluates herself positively as the moral authority, which appears to be accepted by Tina and the other girls at the table (see also Bucholtz \& Hall 2005:593). Danielle is thus successful in creating a 'visible multiparty consensus' against Clare (Goodwin 1990:248). 
This short extract demonstrates how peer-group identities are continually constructed through interactional practices, including right dislocation. Danielle was very popular with her fellow pupils and also with the teachers. In an interview, the class teacher described her as "a shining star" (Interview, 29 January 2007). In my field notes I make my own note about Danielle.

Danielle is a really nice girl. She's quiet and quite studious in class but she obviously gets on well with a lot of the other children in the playground. She won the merit badge this week (a weekly award given out to one member of the class in assembly every Friday). (Field notes, 20 October 2006)

In a later observation, a less popular pupil, Rachel, tells me that Danielle can be "very bossy" and a "bully" (Field notes, 3 November 2006). Two weeks later, Rachel confides in me that Danielle "likes to think that she's the most popular girl in the class and that she's the best at everything" and "seems to have Jane, Gemma, Hannah, and Clare hypnotised" (Field notes, 17 November 2006). Overall, then, Danielle appears to be the prototypical 'popular' girl: able to do well in class and favoured by her teachers, while also being at the centre of the peer-group and policing the boundaries of that group using whatever means necessary.

The target of Danielle's evaluation, Clare, was a very different kind of girl, in appearance as well as in character. I can vividly remember Danielle's long blond hair always tied up neatly in a ponytail, while Clare's hair was wild and unkempt. The teacher who told me that Danielle was "a shining star" also told me that Clare "falls in and out of friends with people a lot", and this was my impression of her too. My field notes reveal multiple references to the volatility of Clare's relationships, including a comment from a teaching assistant that Clare "would find an argument in an empty room" (Field notes, 12 January 2007). My overall impression of Clare, then, was of a confident, outspoken girl who regularly courted confrontation and struggled to integrate fully into the main girls' peer-group (but who was not overly concerned about this). The stance taken by Danielle on lines 30-31 of extract (1), and the way Tina aligns with it, reinforces this well-established peergroup hierarchy, where Danielle is at the top and Clare firmly on the periphery of the girls' friendship group.

Clare's peripheral role might help to explain why there is only one example in the data in which she uses a personal pronoun tag, and it is the less risky first person tag, in which she evaluates herself rather than others (I'm a magician, $m e$ ). In contrast, there are five personal pronoun tags attributable to Danielle, including three third person tags. One of these occurs just a few minutes after Extract 1, when she negatively evaluates one of the 'dinner ladies' on duty in the dining hall (who also happens to be her mother) with the comment "She's like Jamie Oliver now, her". Jamie Oliver is a UK-based celebrity chef whose campaign to make school meals healthier was televised in a documentary aired in 2005 (at the beginning of my fieldwork at Ironstone Primary). Danielle is negatively evaluating her mother as being "like Jamie Oliver" because she had intervened in the girls" 
conversation to encourage Danielle to eat the healthier items in her lunch box. While there is no evaluative lexis in Danielle's comment, the negative assessment is indexed through shared assumptions in the peer-group about Jamie Oliver's unwelcome efforts to change the way they eat at school and through the use of right dislocation, which has a long-standing association with emphatic evaluation, and in this community, with negative evaluation in particular. Danielle's comment is clearly received as a negative evaluation by Tina who appears shocked and responds with "Oh my God". In taking this irreverent evaluative stance, Danielle distances herself from her mother (who she positions as being part of a group of interfering adults) and positively situates herself as independent of adult authority.

Overall, right dislocated pronoun tags were a resource used by the children to explicitly signal their desire to align with some individuals (or objects or ideas) and/or to distance themselves from others, and in the process, they were often styling their own identities (e.g. peer-group leader). The use of second and third person tags to explicitly position OTHERS was a relatively common strategy at working-class Ironstone Primary; but these tags were largely absent from the Murrayfield data. ${ }^{5}$ Moreover, similar patterns emerged in data collected by Emma Moore in a school in Bolton, north-west England, suggesting that these classrelated differences are not unique to Teesside.

Moore (2003) analysed right dislocation in her study of style and identity in a Bolton high school ('Midlan High'). She identified four 'communities of practice' amongst the adolescent girls she studied. Each exhibited different social-class orientations, evaluated on the basis of the forms of practice in which the girls engaged, their contact with other communities beyond their high school, and their aspirations. Based on these practices, Moore described the adolescents in the 'Popular' and 'Townie' communities of practice as being 'working-class oriented' and those in the 'Eden-Village' and 'Geek' communities of practice as 'middle-class oriented'. Girls across all communities of practice used first person pronoun tags (though these were used more frequently by the working-class oriented groups), but second and third person tags were used predominantly by the Townies and Populars (Figure 3; see also Moore \& Snell 2011). The Eden Village and Geek girls generally avoided these tags, just as the children at Murrayfield Primary had avoided them. Further, the Townies and Populars frequently used second and third person tags to take negative evaluative stances, just like the children in Ironstone Primary. Contrary to the dominant association between vernacular forms and in-group solidarity, then, right dislocated pronoun tags were regularly used across both the Teesside and Bolton data to attribute explicit negative evaluations, and to draw social boundaries and negotiate status differentials within the peer-group.

A second feature that appears to problematise the conventional link between local vernacular and in-group solidarity is the salient local dialect form howay. This form is unique to north-east England, and thus may be primed to have even greater local significance. As with right dislocated personal pronoun tags, it was used more frequently in Ironstone Primary (forty-two tokens) than in Murrayfield 


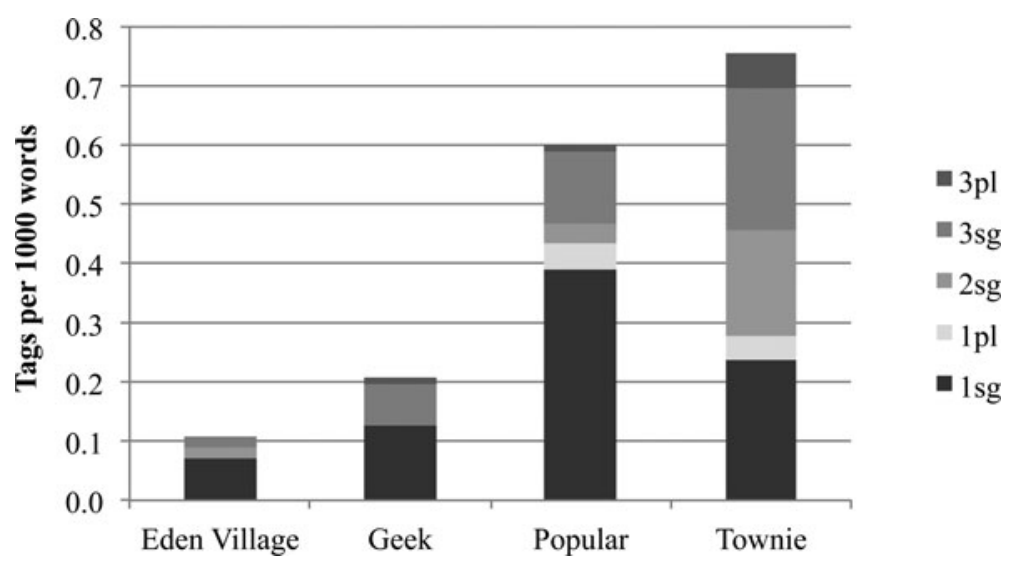

FIGURE 3. Distribution of right dislocated pronouns at a Bolton high school.

Primary (seven tokens) and occurred only in informal peer-group interaction (conforming again to familiar quantitative class-based differences). Referentially, howay means something like 'come on', and it functions generally as a directive (e.g. Howay, let's go), but the precise meanings associated with this form are indeterminate and often not accessible to outsiders. This indeterminacy in meaning is apparent in Clare's use of howay in extract (1).

In order to understand both the meaning and force of howay on line 12 of extract (1) we need to understand, first, that the girls are embroiled in a recurring debate about food trades. We have to take account of the fact that Clare is responding to Danielle's claim (on lines 4-6) that she has given her share of Clare's much coveted chocolate bar to Tina, and also to Tina's denial (on lines 7-9). And we need to pay particular attention to the first part of Clare's reply. Clare's initial response on line 10 ("what are you eating now then") is interrogative in form but does not appear to function as a question. This is confirmed later, on lines 14 to 16, where it becomes clear that Clare already knows what Danielle is eating, and thus could not have been asking a genuine information-seeking question on line 10. Instead Clare's utterance has the force of a directive (e.g. 'Show me what you're eating') or a challenge (e.g. 'Prove you haven't got a piece'). The use of clause-final then supports the idea that Clare is making a challenge, because it sets up a contrast with Danielle's previous utterance (e.g. 'If you really haven't got one, what are you eating now then?'). Clare's use of howay on line 12 reformulates and further intensifies the challenge. This use of howay might be glossed as something like 'Come on then, show me what you're eating'. Taken together, Clare's stance on lines 10 to 12 is fairly aggressive, and the challenge obvious, but Danielle appears not to take it too seriously, perhaps because of her superior standing within the peer group. Danielle treats Clare's utterance as a straightforward question when she replies on line 13 and laughs playfully. 
There were many other instances in which speakers used howay to make challenges and take assertive stances. Extract (2) was recorded when Ironstone Primary pupil Robert was wearing the radio-microphone. Nine-year old Robert was a leader in the peer group and rated highly by his teacher. In this extract, he is on the playground during the morning break and is involved in a game of Bulldog. This is a tag-based game common across England (and no doubt elsewhere) in which one or two players are selected to be the 'bulldogs' and must stand in the middle of the playground. The other players stand at one end of the playground and try to run to the other end without being caught by the bulldogs. If they are caught, they must also become bulldogs. As the extract begins, Robert is in a tricky situation because he is being unfairly marked by one of the bulldogs.

(2) Howay, you can't guard!

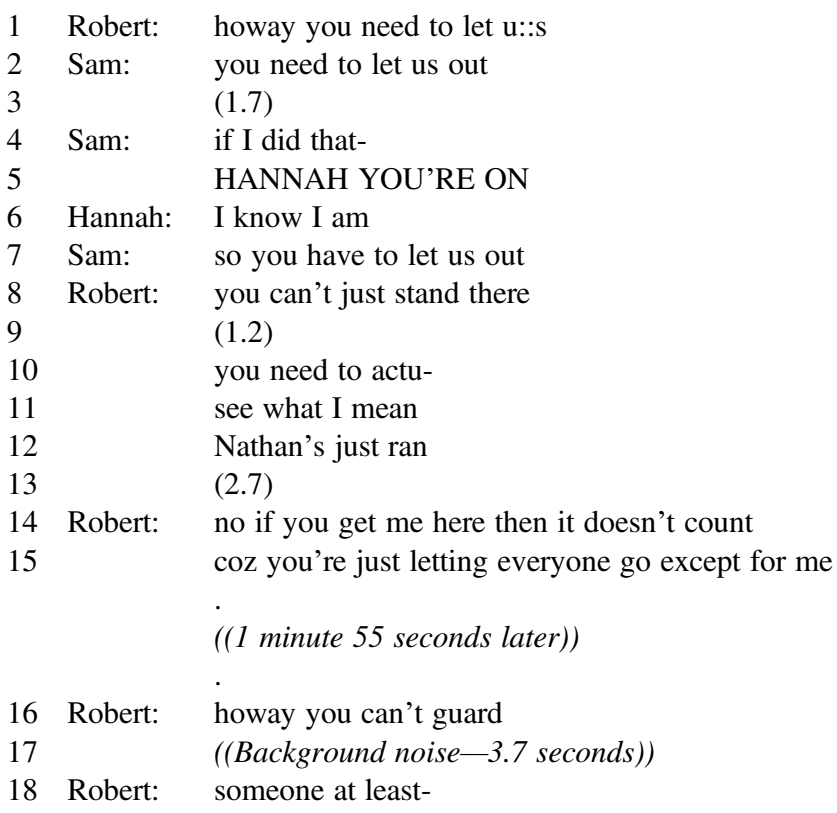

Robert's utterance on line 1 is directed to the bulldog because that person is standing directly in front of Robert and Sam, not giving them a fair chance to run. So the utterance means something like 'come on, you need to move out of the way and at least let us try'. Sam builds on Robert's utterance repeating "you need to let us out" (line 2) and then "you have to let us out" (line 7), thus demonstrating alignment with Robert. Together they take a collaborative stance against their interlocutor, who is negatively evaluated as flouting the implicit rules and 'spirit' of the game. Robert goes on to explicate these rules on lines 8-15, and 
makes the authoritative judgment, "no if you get me here then it doesn't count coz you're just letting everyone go except for me" (lines 14-15). Around two minutes later, the same situation arises again, and Robert again intervenes: "howay you can't guard" (line 16, meaning 'you can't stand in front of us'). The use of howay here, and elsewhere, marks a change in footing. There's a change in what Goffman refers to as the 'production format' of the utterance (Goffman 1981:128): Robert remains 'animator' and 'author' of his words, but now speaks on behalf of a wider moral authority (a change in the 'principal' of the utterance), in the name of 'we' not merely ' $I$ '. Robert is appealing to a shared sense of what is considered right, fair, and acceptable within this game, and within the peer group more generally, and howay encapsulates this appeal. So the meaning of "howay you can't guard" (line 16) is actually something like 'come on, don't stand guard over us; it's not fair, AND YOU KNOW IT'. Although fleeting, the stances taken by Robert in this episode, and the way that others align with him, serve to reinforce his identity as a confident peer-group leader. At the same time, his peer-group status enables him to take authoritative and confrontational stances in order to challenge his peers and police the social order, and howay was a useful resource in this endeavour.

The precise meanings indexed by howay were continually (re)negotiated by the children as they interacted together. But interactional analysis of all forty-nine occurrences in the data set did reveal some consistency in use. The contexts in which howay emerged were usually characterized by peer-group tension and contestation. Speakers used this form to take stances of authority in relation to the dispute and of opposition towards interlocutors, often with an appeal to some shared sense of what is considered reasonable behaviour. This comes out quite clearly in the bulldog example, but it is also evident in extract (1), where Clare tries to police Danielle's behaviour, albeit with limited success. The following additional examples are taken from the data collected across both schools.

- No howay because (1.2) No: because there's- (.) no way we can. Why don't we use this one?

(Clare, Ironstone Primary, arguing with Hannah about which craft materials to use for a shared art project.)

- Aw howay Andrew, you're going to hit me.

(Danielle, Ironstone Primary, trying to discourage unwanted attention from a boy in the playground.)

- Howay, I haven't put any bit in.

(Holly, Murrayfield Primary, who feels she is not being allowed to contribute to a group task.)

- Howay, where's Matty man? He's supposed to be going in goal.

(Daniel, Murrayfield Primary, complaining when his team concedes a goal because they do not have a goalkeeper.) 
Interactional analysis makes clear that howay and pronoun tags have specific value for speakers and others in the local community; they have a local use-value (Skeggs 2004) that is at least partly independent of the (largely negative) exchange-value Teesside dialect forms can expect to accrue on the standard language market. However, it does not appear that the children used these features of their local dialect to foreground in-group solidarity in opposition to the status associated with 'standard' forms. On the contrary, they used howay and pronoun tags to take authoritative and evaluative stances that were consequential in negotiating hierarchy and peer-group status. That said, if we are interested in fully understanding the social meaning of variation, it is important that we focus not only on linguistic form and situated use (as per the above analysis), but also on ideology, and importantly, on how all three relate to each other. We must account for the fact that the processes of local meaning making that are uncovered in interactional analyses are being mediated by more widely circulating ideologies of language and class (and place, gender, etc.), which both constrain and are a product of individual speakers' actions. With this in mind, I return to Ochs' $(1992,1996)$ model of indexicality.

It is possible that ideologies of solidarity are part of the "culturally constructed valences' (Ochs 1996:417) associated with the Teesside dialect forms examined in this article, even though more immediate indexicalities of stance and act are most relevant for speakers/hearers when they use/interpret these forms in interaction (see also Pujolar 2001:206; Rampton 2006a:303-308). This is seen perhaps most clearly with howay. The contexts in which howay emerged - which often involved an appeal to some shared sense of peer-group justice - suggest a link, somewhere in its indexical history, with ideologies of working-class solidarity (see also Coupland 2001:201-202). This indexical history includes, for example, an association with Newcastle United Football club, for whom the battle cry is "Howay the lads!" (see also Snell 2017). These class-linked meanings might feed into interactional use in a range of ways. For example, it is possible that components of working-class ideology, such as toughness and egalitarianism, as well as solidarity, help to constitute Robert's authority in relation to the local social and moral order (= epistemic stance) and his appeal to fair play in taking corrective action (= social act). Robert's stance is confrontational, but some more general sense of solidarity may serve to mitigate the potential face-threat and thus retain the spirit of camaraderie in the playground game (see also Bucholtz's (2009) analysis of the Mexican American youth slang term güey and Kiesling's (2004) analysis of dude). Likewise, while right dislocated pronoun tags were often used to express explicit and unmitigated negative evaluation, it might be that such bold discourse moves depend on underlying relations of intimacy and solidarity within the community in order to function (see also Dunk 1991). Certainly in Danielle's evaluation of her mother ("She's like Jamie Oliver, her, now"), we can assume a close bond between the speaker and the 
object of the evaluation, and venture that this bond is precisely what emboldened Danielle to take such a defiant stance (see also Moore 2012:75); but more broadly, the fact that such candid and unmitigated stances are acceptable within the peer group is indicative of close bonds within the community, which speakers can be confident are unlikely to be broken through open evaluation. To be clear, personal pronoun tags and howay were used in the interactional moment to construct stances of opposition, assert peer-group status, and often negatively evaluate or restrict the behaviour of others. However, it seems likely that these fleeting interactional stances simultaneously drew upon more enduring class ideologies and community values, and solidarity is part of this bigger picture.

To the extent that groups of speakers share the same (or similar) ideological value-systems, we might expect to see similar patterns of linguistic behavior at a local level, which in turn build into the macrosocial patterns of variation that have been well documented in the sociolinguistic research literature: 'Individuals within what we conventionally recognize to be meaningful social categories enact dialect personas with sufficient uniformity for survey researchers to detect numerical patterns of stratification' (Coupland 2001:75). This goes some way to explaining the similarities in the Teesside and Bolton data (I return to this issue in the conclusion). The notion that dominant ideologies of class (including ideas about status and solidarity) may circulate in the larger meaning potential or 'valence' of a specific dialect also helps to explain the robust findings from language attitudes research, which have shown consistently that reactions to 'standard' versus 'vernacular' speech tend to cohere around the dimensions of status and solidarity. The aural stimuli used in language attitudes research cannot capture the subtle nuances of meaning that are communicated via social stances and acts in face-toface interaction (Garrett, Coupland, \& Williams 1999:323; Rampton 2006b:2-3); thus what participants are reacting to when they hear these recordings are the wider cultural ideologies associated with the recorded voices.

\section{O N C L U S I O N}

Status and solidarity are clearly important social meanings, which surface at the micro-level of interaction, in the construction of local identities, and at the macrolevel of class ideologies. These concepts emerge most clearly as contrasting dimensions of language use and social relations, as suggested by Woolard (1985), where there is a marked 'sense of difference' (Doran 2004:114) between oppositional groups, and in particular, where one of these groups is dominant and the other marginalised (e.g. Estate Class vs. Non-Estate Class, jocks vs. burnouts, les bourgeois vs. minority-ethnic youth). In these situations, speakers may turn to their local vernacular as a means of marking group solidarity and rejecting the institutionalized status of the dominant variety. However, it may be more typical for speakers, in their day-to-day lives, to focus more on relations within their own communities than on wider societal relations 
(Silverstein 2016:58). This was the case for the children in the Teesside study, at least within spontaneous peer interaction where mainstream norms and values were not relevant. These children used dialect forms that LACK status within the dominant sociolinguistic economy in order to ASSERT status in local interactional use. This suggests that there are at least two different ways in which social status relations may be conceived, and as analysts, we need to be clear about which level we want to privilege, when, why, and with what gains and losses. At one level, status is to do with large-scale judgements about an individual or group's position in society, often conceptualized in terms of a class hierarchy. More locally, status relates to patterns of power at a micro-level and is something that is interactionally achieved. It is no coincidence that, across both schools, it was the confident, outgoing children who used howay and right dislocated pronoun tags most frequently, since these were the children most likely to take assertive and authoritative stances. The status of these children likely contributed to the indexical meanings of howay and pronoun tags. At the same time, the use of these forms also helped to constitute their peer-group status.

It was the working-class children who used howay and pronoun tags most frequently to take stances of opposition and negative evaluation/alignment. These stance meanings were broadly shared by all of the children who used these forms (or at least there is some evidence for this in the fifty hours of recordings I analysed). Moreover, working-class adolescents in a Bolton high school used pronoun tags to do similar kinds of social work. This suggests, first, that differences in the frequency of use of vernacular forms between class-differentiated groups might best be explained by consideration of the different social goals, acts, and stances in which they are engaged; and second, that these social goals, acts, and stances may constitute a form of class-based practice that endures across social (in this case, age) and geographic boundaries. I posed similar hypotheses in an earlier article (Snell 2010) in which I analysed the children's use of another salient feature of the local dialect, possessive $m e$. This form was used most frequently by the working-class children, and they used it specifically to construct stances of stylised negative affect or transgression, often tempered by playfulness or a lack of commitment to the utterance. On the basis of this analysis I asked: 'Does habitual use of a particular kind of interactional stance... cumulatively construct a particular kind of working-class identity (e.g. characterised by humour, playfulness, the policing of social boundaries), or at least an aspect of that identity, which can be contrasted with [a] middle-class identity?'. A similar question arises here again, only this time it finds greater force from the fact that issues of negative alignment and boundary marking came into play again for the working-class participants when they used howay and pronoun tags, and by the addition of the Bolton data. All of this points to the possibility that stances of negative alignment or affect and explicit positioning of interlocutors may be part of a more widely shared working-class sensibility. Other researchers have been thinking along similar lines. For example, Kiesling (2018:251) argues that 'class manifests not just in consumption, practices, and beliefs, but also in 
affects and desires' and suggests that performing a working-class identity is 'accomplished by taking stances that focus on specific forms of negative alignment and negative assessment' (see also Moore 2012; Johnstone 2013:192-94; Block 2015:9; Eckert 2016:80). More broadly, it was mooted decades ago that when it comes to grammatical and discoursal variation, it is difficult to maintain that class differentiation is simply differentiation of form (e.g. Lavandera 1978; Dines 1980); rather we have to consider that speakers occupying different class positions in society may be using language to fulfil different functions, i.e. TO DO DIFFERENT THINGS (Eckert 2008:467). This position has not been taken up (likely due to the risk that this argument may be misinterpreted as evidence of linguistic deficit on the part of working-class speakers), but it seems to be a productive avenue for future ethnographic research. This research would need to focus not only on the speech of working-class participants (as has been the bias in sociolinguistics, including in my own work) but also on middle-class participants. In relation to my data, for example, I would need to investigate how, and to what extent, the Murrayfield Primary participants used language to evaluate themselves and others, negotiate relations of status and solidarity, and construct peer-group hierarchies. One possibility is that the children at Murrayfield Primary simply used different linguistic resources to make evaluations and construct stances of opposition. For example, Macaulay (2005) found that middle-class speakers in the west of Scotland (Ayr and Glasgow) used adverbs and adjectives more frequently than working-class speakers to make evaluations (while working-class speakers made greater use of right dislocation, though he does not give any examples involving pronoun tags). However, the middle-class evaluations were of the people, places, and events that arose in the stories participants told in research interviews and dyadic conversations organised by a researcher. These evaluations are therefore quite different to the explicit positioning of interlocutors that were associated with the working-class participants in my data and which I have argued may be part of a more widely shared working-class sensibility.

Bringing all of this back to the issue of vernacular maintenance with which I began, it may be that conflict between status- and solidarity-based ideologies is a key force in the continued use of local vernacular within some communities; but elsewhere (or in addition), we may also need to look more closely at community internal values, which would include investigating the local use-value of dialect forms. Such an approach might help us to account for the durability and consistency in use of features of spoken discourse (such as tags), which we might otherwise expect to be susceptible to change (Timmis 2010: 16-17), and to better understand why local vernaculars remain strong, even in the face of overt stigmatisation. Dialect forms that fulfil important functions in a community are unlikely to disappear. We also need to consider how use-value is mediated by wider class ideologies and take seriously the possibility that local vernaculars are intimately connected to classed subjectivities. 


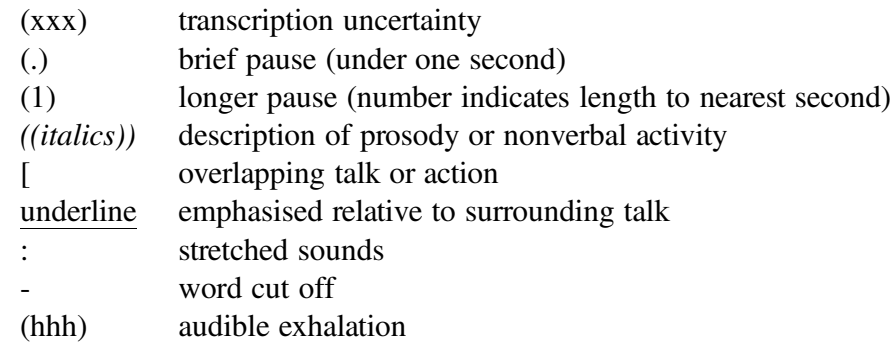

\section{N O T E S}

*I would like to express my thanks to Ben Rampton for constructive comments on an early draft of this article, and to two anonymous reviewers and Jenny Cheshire for their thoughtful and supportive feedback. Any remaining errors or shortcomings in the final article are of course entirely my own. I am indebted to the staff and pupils at Ironstone Primary and Murrayfield Primary for allowing me to spend time in their schools and for their warmth and generosity.

${ }^{1}$ In the rest of the article I use the terms 'vernacular' and 'standard' to refer to a broad distinction between: (i) local ways of speaking that are regionally and/or socially marked and often stigmatised, and (ii) widespread, legitimised ways of speaking that tend to be considered prestigious. I do so with caution, however, as I accept Coupland's (2009:285) point that 'we have to be wary of overconsolidating these terms' (see also Coupland 2016). I also maintain the use of scare quotes around 'standard' throughout to align with the perspective that 'standard' English is a sociohistorical construction, not a linguistic fact (Crowley 1989; J. Milroy 1999; Coupland 2000).

${ }^{2}$ I acknowledge that there are limitations in my use of these terms, but it is outside of the scope of this article to unpack the complexity of 'class' as a sociolinguistic concept (see instead Block 2014 and especially Rampton 2006a; for a recent sociological account of the changing nature of class in Britain see Savage at al. 2013).

${ }^{3}$ Transcription conventions are given in the appendix.

${ }^{4}$ nicked is a colloquial British term for 'stole'.

${ }^{5}$ The only exception is a third person tag used by Michelle in describing one of her neighbours, who has been rude to Michelle's friend: "She's horrible, her". There are no examples in which Murrayfield Primary participants used pronoun tags to evaluate members of the peer group. It is also perhaps worth noting that the first person pronoun tags used by children at Murrayfield were not explicitly evaluative: "I want that one, me", "I'm being first in line, me", "I'm not playing, me".

\section{R E F E R E N C E S}

Aijmer, Karin (1989). Themes and tails: The discourse functions of dislocated elements. Nordic Journal of Linguistics 12:137-53.

Beal, Joan (2004). English dialects in the north of England: Morphology and syntax. In Bernd Kortmann, Kate Burridge, Rajend Mesthrie, Edgar W. Schneider, \& Clive Upton (eds.), A handbook of varieties of English, vol. 2: Morphology and syntax, 114-41. Berlin: Mouton de Gruyter.

Bell, Allan (1984). Language style as audience design. Language in Society 13(2):145-204.

Biber, Douglas; Stig Johansson; Geoffrey Leech; Susan Conrad; \& Edward Finegan (1999). Longman grammar of spoken and written English. Harlow: Longman. 


\section{JULIA SNELL}

Bishop, Hywel; Nikolas Coupland; \& Peter Garrett (2005). Conceptual accent evaluation: Thirty years of accent prejudice in the UK. Acta Linguistica Hafniensia 37:131-54.

Block, David (2014). Social class in applied linguistics. Abingdon: Routledge.

(2015). Social class in applied linguistics. Annual Review of Applied Linguistics 35:1-19.

Bourdieu, Pierre (1977). The economics of linguistic exchanges. Social Science Information 16(6):64568.

(1991). Language and symbolic power. Cambridge: Polity Press.

, \& Luc Boltanski (1975). Le fétichisme de la langue. Actes de la Recherché en Sciences Sociales $4: 2-32$.

Bucholtz, Mary (2009). From stance to style: Gender, interaction, and indexicality in Mexican immigrant youth slang. In Alexandra Jaffe (ed.), Stance: Sociolinguistic perspectives, 146-70. New York: Oxford University Press.

, \& Kira Hall (2005). Identity and interaction: A sociocultural linguistic approach. Discourse Studies 7(4-5):585-614.

Carter, Ronald, \& Michael McCarthy (1995). Grammar and the spoken language. Applied Linguistics 16:141-58.

— \& Michael McCarthy (1997). Exploring spoken English. Cambridge: Cambridge University Press.

; Rebecca Hughes; \& Michael McCarthy (2000). Exploring grammar in context. Cambridge: Cambridge University Press.

Cheshire, Jenny (1982). Variation in an English dialect. Cambridge: Cambridge University Press.

(2005). Syntactic variation and spoken language. In Leonie Cornips \& Karen Corrigan (eds.), Syntax and variation: Reconciling the biological and the social, 81-106. Amsterdam: John Benjamins.

Coupland, Nikolas (1980). Style-shifting in a Cardiff work setting. Language in Society 9:1-12.

(1984). Accommodation at work: Some phonological data and their implications. International Journal of the Sociology of Language 46:49-70.

(2000). Sociolinguistic prevarication about 'standard English'. Journal of Sociolinguistics 4 (4):622-34.

(2001). Language, situation, and the relational self. In Penelope Eckert \& John R. Rickford (eds.), Style and sociolinguistic variation, 185-210. Cambridge: Cambridge University Press.

- (2007). Style: Language variation and identity. Cambridge: Cambridge University Press. (2009). The mediated performance of vernaculars. Journal of English Linguistics 37(3):284300.

(2016). Labov, verncularity and sociolinguistic change. Journal of Sociolinguistics 20(4):40930.

Crowley, Tony (1989). The politics of discourse: The standard language question in British cultural debates. London: Macmillan.

Dines, Elizabeth R. (1980). Variation in discourse — 'and stuff like that'. Language in Society 9:13-31.

Dodsworth, Robin (2010). Social class. In Paul Kerswill, Barbara Johnstone, \& Ruth Wodak (eds.), The SAGE handbook of sociolinguistics, 192-207. London: SAGE.

Doran, Meredith (2004). Negotiating between Bourge and Racaille: Verlan as youth identity practice in suburban Paris. In Aneta Pavlenko \& Adrian Blackledge (eds.), Negotiation of identities in multilingual contexts, 93-124. Clevedon: Multilingual Matters.

Drummond, Rob (2016). Leave off, will you? Britain should celebrate 'regional' accents. The Conversation. Online: https://theconversation.com/leave-off-will-you-britain-should-celebrate-regionalaccents-67952; accessed September 5, 2017.

Du Bois, John (2007). The stance triangle. In Robert Englebretson (ed.), Stancetaking in discourse, 13982. Amsterdam: John Benjamins.

Dunk, Thomas (1991). It's a working man's town: Male working-class culture. Montreal: McGillQueen's University Press. 


\section{SOLIDARITY, STANCE, AND CLASS IDENTITIES}

Durham, Mercedes (2007). 'It's altered a lot has York': Right dislocation in Northern England. York Papers in Linguistics 8:61-71.

Eckert, Penelope (1989). Jocks and burnouts: Social categories and identity in the high school. New York: Teachers College Press.

(2000). Linguistic variation as social practice: The linguistic construction of identity at Belten High. Oxford: Blackwell.

- (2008). Variation and the indexical field. Journal of Sociolinguistics 12(4):453-76.

(2012). Three waves of variation study: The emergence of meaning in the study of sociolinguistic variation. Annual Review of Anthropology 41:87-100.

(2016). Variation, meaning and social change. In Nikolas Coupland (ed.), Sociolinguistics: Theoretical debates, 68-85. Cambridge: Cambridge University Press.

Garner, Richard (2013). Teacher 'told to sound less northern' after southern Ofsted inspection. The Independent, 18 November 2013. Online: http://www.independent.co.uk/news/uk/home-news/ teacher-told-to-sound-less-northern-after-southern-ofsted-inspection-8947332.html; accessed September 5, 2017.

Garrett, Peter; Nikolas Coupland; \& Ann Williams (1999). Evaluating dialect in discourse: Teachers' and teenagers' responses to young English speakers in Wales. Language in Society 28(3):321-54.

Giles, Howard (1970). Evaluative reactions to accents. Educational Review 22:211-27.

, \& Peter F. Powesland (1975). Speech style and social evaluation. London: Academic Press.

Goffman, Erving (1981). Forms of talk. Oxford: Blackwell.

Goodwin, Majorie Harness (1990). He-said-she-said: Talk as social organization among black children. Bloomington: Indiana University Press.

(2006). The hidden life of girls: Games of stance, status, and exclusion. Malden, MA: Blackwell.

Hiraga, Yuko (2005). British attitudes towards six varieties of English in the USA and Britain. World Englishes 24(3):289-308.

Holmes-Elliott, Sophie, \& Erez Levon (2017). The substance of style: Gender, social class and interactional stance in /s/-fronting in southeast England. Linguistics 55(5):1045-72.

Huddleston, Rodney, \& Geoffrey K. Pullum (2002). The Cambridge grammar of the English language. Cambridge: Cambridge University Press.

Jaffe, Alexandra (ed.) (2009). Stance: Sociolinguistic perspectives. Oxford: Oxford University Press. (2016). Indexicality, stance and fields in sociolinguistics. In Nikolas Coupland (ed.), Sociolinguistics: Theoretical debates, 86-112. Cambridge: Cambridge University Press.

Jaspers, Jürgen (2011). Strange bedfellows: Appropriations of a tainted urban dialect. Journal of Sociolinguistics 15(4):493-524.

Johnstone, Barbara (2013). Speaking Pittsburghese: The story of a dialect. Oxford: Oxford University Press.

— ; Jennifer Andrus; \& Andrew E. Danielson (2006). Mobility, indexicality, and the enregisterment of 'Pittsburghese'. Journal of English Linguistics 34(2):77-102.

Kiesling, Scott (2004). Dude. American Speech 79(3):281-305.

(2009). Style as stance: Stance as the explanation for patterns of sociolinguistic variation. In Alexandra Jaffe (ed.), Stance: Sociolinguistic perspectives, 171-94. Oxford: Oxford University Press.

(2018). Youtube Yinzers: Stancetaking and the performance of 'Pittsburghese'. In Reem Bassiouney (ed.), Identity and dialect performance: A study of communities and dialects, $\mathrm{xx}-\mathrm{xx}$. London: Routledge.

Kirkham, Sam (2015). Intersectionality and the social meanings of variation: Class, ethnicity, and social practice. Language in Society 44:629-52.

Kristiansen, Tore (2011). Attitudes, ideology and awareness. In Ruth Wodak, Barbara Johnson, \& Paul Kerwsill (eds.), The SAGE handbook of sociolinguistics, 265-78. London: SAGE.

Labov, William (1966). The social stratification of English in New York City. Washington, DC: Center for Applied Linguistics. 


\section{JULIA SNELL}

(1972a). Sociolinguistic patterns. Philadelphia: University of Pennsylvania Press.

(1972b). Language in the inner city. Oxford: Basil Blackwell.

Lavandera, Beatriz R. (1978). Where does the sociolinguistic variable stop? Language in Society 7:17182.

Le Page, R. B., \& Andrée Tabouret-Keller (1985). Acts of identity: Creole-based approaches to language and ethnicity. Cambridge: Cambridge University Press.

Macaulay, Ronald (2005). Talk that counts: Age, gender, and social class differences in discourse. Oxford: Oxford University Press.

Madsen, L. M. (2016). Social status relations and enregisterment: Integrated speech in Copenhagen. In Karel Arnaut, Martha Karrebæk, Massimiliano Spotti, \& Jan Blommaert (eds.), Engaging superdiversity: Recombining spaces, times and language practices, 147-69. Bristol: Multilingual Matters.

Milroy, James (1999). The consequences of standardisation in descriptive linguistics. In Tony Bex \& Richard J. Watts (eds.), Standard English: The widening debate, 16-39. Abingdon: Routledge.

— \& Lesley Milroy (1997). Varieties and variation. In Florian Coulmas (ed.), The handbook of sociolinguistics, 47-64. Oxford: Blackwell.

Milroy, Lesley (1980). Language and social networks. Oxford: Basil Blackwell.

Moore, Emma (2003). Learning style and identity: A sociolinguistic analysis of a Bolton high school. Manchester: University of Manchester Ph.D. thesis.

(2012). The social life of style. Language and Literature 21:66-83.

- \& Julia Snell (2011). 'Oh, they're top, them': Right dislocated tags and interactional stance. Studies in Language Variation, Proceedings from ICLaVE 5, 97-110. Amsterdam: John Benjamins.

Ochs, Elinor (1992). Indexing gender. In Alessandro Duranti \& Charles Goodwin (eds.), Rethinking context: Language as an interactive phenomenon, 335-58. Cambridge: Cambridge University Press.

(1996). Linguistic resources for socializing humanity. In John Gumperz \& Stephen Levinson (eds.), Rethinking linguistic relativity, 407-37. Cambridge: Cambridge University Press.

Office for National Statistics (2005). 2001 Census aggregate data (Edition: 2005). UK Data Service. doi: http://dx.doi.org/10.5257/census/aggregate-2001-1.

Podesva Robert J.; Sarah J. Roberts; \& Kathryn Campbell-Kibler (2001). Sharing resources and indexing meanings in the production of gay styles. In Kathryn Campbell-Kibler, Robert J. Podesva, Sarah J. Roberts, \& Andrew Wong (eds.), Language and sexuality: Contesting meaning in theory and practice, 175-89. Stanford, CA: CSLI Publications.

Pujolar, Joan (2001). Gender, heteroglossia and power: A sociolinguistic study of youth culture. Berlin: Mouton de Gruyter.

Quirk, Randolph; Sidney Greenbaum; Geoffrey Leech; \& Jan Svartvik (1985). A comprehensive grammar of the English language. London: Longman.

Rampton, Ben (2006a). Language in late modernity: Interaction in an urban school. Cambridge: Cambridge University Press.

- (2006b). Language in late modernity: Interaction in an urban school: Supplementary data and discussion. Cambridge: Cambridge University Press.

- (2010). Crossing into class: Language, ethnicities and class sensibility in England. In Carmen Llamas \& Dominic Watt (eds.), Language and identities, 134-43. Edinburgh: Edinburgh University Press.

(2011). Style contrasts, migration and social class. Journal of Pragmatics 43:1236-50.

Rickford, John R. (1986). The need for new approaches to social class analysis in sociolinguistics. Journal of Communication 6:215-21.

Savage, Mike; Fiona Devine; Niall Cunningham; Mark Taylor; Yaojun Li; Johs Hjellbrekke; Brigitte Le Roux; Sam Friedman; \& Andrew Miles (2013). A new model of social class: Findings from the BBC's Great British Class Survey experiment. Sociology 47(2):219-50.

Sharma, Devyani, \& Ben Rampton (2015). Lectal focusing in interaction: A new methodology for the study of style variation. Journal of English Linguistics 43(1):3-35. 


\section{SOLIDARITY, STANCE, AND CLASS IDENTITIES}

Shorrocks, Graham (1999). A grammar of the dialect of the Bolton area, part II: Morphology and syntax. Frankfurt am Main: Peter Lang.

Skeggs, Beverley (2004). Class, self, culture. London: Routledge.

Silverstein, Michael (1985). Language and the culture of gender: At the intersection of structure, usage, and ideology. In Elizabeth Mertz \& Richard Parmentier (eds.), Semiotic mediation: Sociocultural and psychological perspectives, 219-59. New York: Academic Press.

- (2016). The 'push' of Lautgesetze, the 'pull' of enregisterment. In Nikolas Coupland (ed.), Sociolinguistics: Theoretical debates, 37-67. Cambridge: Cambridge University Press.

Snell, Julia (2010). From sociolinguistic variation to socially strategic stylisation. Journal of Sociolinguistics 14(5):618-44.

(2013). Dialect, interaction and class positioning at school: From deficit to difference to repertoire. Language and Education 27(2):110-28.

(2015). Linguistic ethnographic perspectives on working-class children's speech: Challenging discourses of deficit. In Julia Snell, Fiona Copland, \& Sara Shaw (eds.), Linguistic ethnography: Interdisciplinary explorations, 225-45. London: Palgrave.

(2017). Enregisterment, indexicality and the social meaning of 'howay': Dialect and identity in north-east England. In Emma Moore \& Chris Montgomery (eds.), Language and a sense of place, 301-324. Cambridge: Cambridge University Press.

Stewart, Mark A.; Ellen B. Ryan; \& Howard Giles (1985). Accent and social class effects on status and solidarity evaluations. Personality and Social Psychology Bulletin 11(1):98-105.

Timmis, Ivor (2010). 'Tails' of linguistic survival. Applied Linguistics 31(3):325-45.

Trudgill, Peter (1972). Sex, covert prestige and linguistic change in urban British English. Language in Society 1:179-95.

Watson, Kevin, \& Lynn Clark (2015). Exploring listeners' real-time reactions to regional accents. Language Awareness 24(1):38-59.

Werner, Oswald J., \& Gordon M. Schoepfle (1989). Systematic field work. Newbury Park, CA: SAGE.

Williams, Olivia (2013). Primary school tells parents to stop children using slang phrases as it is preventing them from learning 'standard' English. The Daily Mail, 5 February 2013. Online: www.dailymail. co.uk/news/article-2273821/Middlesbrough-parents-clamp-local-expressions-home-children-learnstandard-English.html\#axzz2KWn3AVOG; accessed November 21, 2013.

Woolard, Kathryn (1985). Language variation and cultural hegemony. American Ethnologist 12:73848.

Wright, Joseph (1905). The English dialect grammar. Oxford: Henry Frowde.

(Received 15 January 2018; revision received 13 June 2018; accepted 2 July 2018; final revision received 3 July 2018)

Address for correspondence:

Julia Snell

University of Leeds

Woodhouse Lane

Leeds LS2 9JT, UK

j.snell@leeds.ac.uk 